\title{
Changes in physicochemical components of Astragalus membranaceus fermented with Phellinus linteus
}

\author{
Yeon-Jeong Jang ${ }^{1}$, Eun-Ju Kim ${ }^{1}$, So Young Kim ${ }^{1}$, Yun Hye Lee ${ }^{2}$, \\ Shin-Young Park ${ }^{1 *}$ \\ ${ }^{1}$ Department of Agro- food Resources, National Insitute of Agricultural Science, RDA, Wanju 55365, Korea \\ ${ }^{2}$ Mushroom Research Institute, Gyeonggi Province, ARES, Gwangju 12805, Korea
}

\section{상황버섯균 접종 황기의 배양 중 이화학적 성분변화}

\author{
장연정 $^{1} \cdot$ 김은주 $^{1} \cdot$ 김소영 $^{1} \cdot$ 이윤혜 ${ }^{2} \cdot$ 박신영 $^{1 *}$ \\ 1농촌진흥청 국립농업과학원 농식품자원부 발효식품과, \\ ${ }^{2}$ 경기도농업기술원 버섯연구소
}

\begin{abstract}
This study analyzed the changes in physicochemical components of Astragalus membranaceus (AM) fermented with Phellinus linteus. Moisture content, $\mathrm{pH}$, total acidity, total reducing sugar content, extraction yield, free sugar content, free amino acid and isoflavonoid (calycosin, formononetin) were investigated. The moisture content was increased during fermentation with Phellinus linteus. The $\mathrm{pH}$ level increased while the total acidity significantly decreased during fermentation. The reducing sugar content were in the range of $0.32 \sim 0.61 \%$. The extraction yield using water was higher than that using $80 \%$ ethanol. The major free sugars were identified as glucose, fructose, sucrose and the content of free sugars decreased through fermentation. However, the glucose and sucrose contents of the water extracts were increased. In addition, the free amino acid increased significantly during fermentation. Finally, calycosin and formononetins contents in water extracts of after 30 days of AM fermentaion with Phellinus linteus were $(3.91 \mathrm{mg} / 100 \mathrm{~g})$ and $(1.38 \mathrm{mg} / 100 \mathrm{~g})$, respectively. These results suggest that fermentation with Phellinus linteus could be used to increase the bioactivity of AM. The mycelium-fermented AM could be a valuable source of functional material and edible resource for industry.
\end{abstract}

Key words : Phellinus linteus, Astragalus memvranaceus, physicochemical components

\section{서 론}

상황버섯(Phellinus linteus)은 목질진흙버섯으로도 불리 며, 다년생으로 뽕나무에 자생하는 목재부후균이며, 동의 보감에서 상목이(桑木耳)라는 이름으로 탕액편에 기록되어 있고, 본초강목에서는 목이의 항으로 분류하여 상이, 상황 등으로 기록되어 있다. 이러한 상황버섯이 다양한 생리활

*Corresponding author. E-mail : soyoenj@korea.kr Phone : 82-63-238-3625, Fax : 82-63-238-3843

Received 23 August 2016; Revised 22 September 2016; Accepted 26 September 2016.

Copyright (c) The Korean Society of Food Preservation. All rights reserved.
성으로 항종양활성, 면역활성 및 항암활성을 가지는 것으 로 보고되며, 그 중에서 Maeda 등(1)의 연구에 의하면 항암 활성이 $96.7 \%$ 라고 보고되어 항암효과가 뛰어난 것으로 널 리 알려져 있다. 귀중한 약재로서 한국에서는 대량으로 재 배되어 식용 및 약용으로 이용되며 기능성 자원으로 활용되 고 있다.(2)

황기(Astragali memvranaceus)는 기운을 보하는 대표적 인 한약재로 성질은 따뜻하고 맛은 달며 한방에서 지한(止 汗), 이노, 강장, 혈압강하 등의 목적으로 사용되고 있다. 약리실험 연구에서는 항염, 이뇨, 강장(3), 혈당강하(4), 면 역증강, 항종양, 항바이러스 작용 등이 있는 것으로 밝혀졌 다(5,6). 또한, 황기는 간 기능을 보호하는 물질을 함유하고 있을 뿐 아니라, isoflavone성분을 함유하고 있어 항산화 
소거능이 우수하며, 항당뇨 기능이 있다고 보고 된 바 있다 (7).

최근에 천연물 소재는 세계적으로 주목받는 분야로 식물 유래 생리활성물질은 성인병 및 대사증후군을 예방하는 기능성소재로서 각광받고 있으며, 천연물로부터 식물화학 물질을 개발하려는 연구가 활발히 진행되고 있다. 기존 천 연물질을 이용한 추출 방법은 주로 용매나 열수 등을 이용 해 단순 추출하거나 액상발효방법을 활용하여 왔지만 효과 가 낮은 한계가 있으나 최근 다양한 기질에서도 자랄 수 있는 진균 곰팡이류 등의 미생물을 활용해 고체 발효함으로 써 발효 대상 기질을 그대로 이용해 생변환 효율을 높이는 기술이 각광받는데 이는 미생물이 식물 섬유소 및 각종 천연물을 분해 및 변환하는 능력이 우수하므로 대부분 식물 유래 천연물질을 발효 대상으로 사용할 수 있는 장점 때문 이다(8,9). 이러한 진균 곰팡이류인 약용버섯균은 항암효과 와 면역증강작용이 뛰어나고, 버섯 균사체는 자실체와 유 사한 생리적 기능을 가지므로(10) 식용 또는 의료용으로 복용 시 독성 및 부작용이 나타나지 않으며(11-13) 기능성 자원으로서의 활용이 주목받고 있다. 이러한 균사체를 식 용이 가능한 곡류나 약용식물 등의 고체재료에 배양하면 별도의 추출 공정 없이 바로 이용하는 것이 가능하며(14), 현재 미생물 이용을 통한 한약재의 효능 증가 및 새로운 효능을 도출하는 연구(15)가 활발히 진행되고 있다.

따라서, 본 연구에서 상황버섯균 균사체를 황기에 배양 하여 기능성뿐만 아니라 이용성을 증진시킨 식품 개발과 더불어 다양한 용도로 쓰일 수 있는 소재를 개발하기 위한 연구의 일환으로 기초연구를 실시하였다.

\section{재료 및 방법}

\section{실험재료}

본 실험에 사용된 균주는 국립원예특작과학원 버섯과에 서 분양받은 상황버섯(Phellinus linteus)균주를 분양받아 본 연구실에서 계대배양하면서 사용하였으며, 상황버섯균 배 양용 약재 황기(Astragali memvranaceus)는 충북 제천산 3 년 근으로(Hanbangchon, Yeongcheon, Korea)에서 구입하여 사용하였다.

\section{균주 배지 및 배양조건}

균의 고체배양용 $\mathrm{MYG}$ 배지(malt extract $1.0 \%$, yeast extract $0.4 \%$, glucose $0.4 \%$, agar $2 \%$ )를 제조하여 사용시 $25^{\circ} \mathrm{C}$ 에서 15 일간 평판 배양한 다음 접종원으로 사용하였 다.

\section{상황버섯균 배양 황기 제조}

황기 $2 \mathrm{~kg}$ 을 톱밥형태로 분쇄한 뒤 황기 및 미강을 $4: 1$
비율로 미강 $0.5 \mathrm{~kg}$ 첨가하고, $2 \mathrm{~L}$ 증류수를 가해 혼합한 후 각 $300 \mathrm{~g}$ 씩 톱밥종균 배양병에 병입 하고, autoclave (Vision Scientific, Co., Ltd., Daejeon, Korea)에서 $120^{\circ} \mathrm{C}, 40$ 분 멸균시킨 다음, 각 배양병에 상황버섯균주를 접종하여 $25^{\circ} \mathrm{C}$ 온도의 incubater(VS-1203PFHLN, Vision Scientific, Co., Ltd., Daejeon, Korea)에서 30일간 배양하며 발효시켰 다. 상황버섯균 배양 황기는 $-80^{\circ} \mathrm{C}$ 초저온냉동기(deep freezer, Ilsin BioBase Co., Ltd., Dongducheon, Korea)에서 24시간 동결시킨 후 동결건조기(freeze dryer, Ilsin BioBase Co., Ltd., Dongducheon, Korea)에서 72시간 동결 건조시킨 것을 마쇄하여 시료로 사용하였다.

상황버섯균 배양 황기의 수분 함량, $\mathrm{pH}$ 및 산도 측정

상황버섯균 배양 황기의 수분 함량은 적외선 수분 측정 기(MS-70, AND Co., Japan)를 이용하여 측정하였으며, $\mathrm{pH}$ 는 시료 $2 \mathrm{~g}$ 을 칭량하여 $8 \mathrm{~mL}$ 의 증류수를 가하여 균질화한 후 $3,000 \mathrm{rpm}$ 에서 15 분간 원심분리한 후 상등액을 취하여 $\mathrm{pH}$ meter(HM-30P, DKK-TOA, Japan)로 측정하였다. 총 산 도는 $\mathrm{pH}$ 측정의 시료와 동일한 시료를 $3,000 \mathrm{rpm}$ 에서 15 분 간 원심분리한 후 시료액 $0.1 \mathrm{~mL}$ 에 $0.9 \mathrm{~mL}$ 의 증류수를 가하여 $10 \mathrm{~mL}$ 로 정용한 후, 지시약 $0.05 \%$ phenolphthalein을 사용하여 $0.1 \mathrm{~N} \mathrm{NaOH}$ 로 $\mathrm{pH}$ 8.3에 도달 할 때까지 적정하였 으며, 적정에 소비된 $\mathrm{NaOH}$ 소비량을 이용하여 acetic aicd 함량(\%)으로 환산하여 총산 함량을 표시하였다. 실험은 3 회 반복하였으며 결과는 평균값표푼편차로 나타내었다.

\section{환원당 측정}

환원당은 dinitrosalicylic acid(DNS)법(16)에 따라 시료 $1 \mathrm{~mL}$ 에 DNS reagent $1 \mathrm{~mL}$ 을 가하여 15 분간 꼻인 다음, 냉각한 후 증류수 $3 \mathrm{~mL}$ 을 첨가하여 UV-visible spectrophoto meter를 이용하여 $546 \mathrm{~nm}$ 의 파장에서 흡광도를 측정하였 다. 이때 당의 정량은 glucose를 표준물질로 사용하여 표준 곡선으로부터 환산하여 함량을 산출 하였다.

\section{추출물 제조 및 추출수율 측정}

추출물 제조는 상황버섯균 접종 황기를 동결건조 한 것 을 사용하여 $80 \%$ 에탄올 추출물 및 열수추출물을 제조하였 다. $80 \%$ 에탄올 추출물의 제조는 다음과 같다. 각 배양물 $5 \mathrm{~g}$ 에 $80 \%$ 에탄올 수용액 $100 \mathrm{~mL}$ 씩 가하여 ultrasonicator (Power Sonic 420, 50/60 HZ, 700W, Hwashin Co., Seoul, Korea)로 1시간 씩 2회 sonication하여 추출한 후 Whatman No. 2 여과지를 이용하여 여과시킨 후, rotary vacuum evaporater(BUCHI, USA)를 이용하여 $50^{\circ} \mathrm{C}$ 이하에서 감압. 농축하였고, 이를 같은 추출용매로 용해하여 본 실험의 분 석용 시료로 사용하였다. 열수추출물의 제조는 다음과 같 다. 각 배양물 $5 \mathrm{~g}$ 에 꼻인 증류수 $100 \mathrm{~mL}$ 을 혼합 후 ultrasonication(Power Sonic 420, 50/60 HZ, 700W, Hwashin 
Co., Seoul, Korea)으로 1시간 씩 2회 sonication하여 추출한 후 Whatman No. 2 여과지를 이용하여 여과시킨 후, rotary vacuum evaporater를 이용하여 $50^{\circ} \mathrm{C}$ 이하에서 감압.농축한 뒤, 이를 같은 추출용매로 용해하여 본 실험의 분석용 시료 로 사용하였다. 추출수율은 각각의 추출물을 동결 건조시 켜서 건조중량을 구한다음 추출물 조제에 사용한 원료 물량 에 대한 백분율로 나타내었다.

\section{유리당 분석}

유리당 분석은 HPLC(Waters 2695, waters Co., Miliford, $\mathrm{MA}, \mathrm{USA}$ )를 이용하여 분석하였다. 상황버섯균 배양 황기 추출물을 희석하여 $0.45 \mu \mathrm{m}$ PVDF membrane filter를 여과 한 것을 시험용액으로 하였고, column은 YMC-PACK Polyamine $\Pi(5 \mu \mathrm{m}, 4.6 \times 250 \mathrm{~mm}, \mathrm{YMC} \mathrm{Co})$ 을 사용하였으 며, mobile phase는 acetonitrile:water 혼합액(75:25, v/v), flow rate는 $1.0 \mathrm{~mL} / \mathrm{min}$, detector는 RI(Waters 2414, Waters Co.)를 사용하여 분석하였다.

\section{아미노산 분석}

유리아미노산은 $80 \%$ 에탄올 추출물에 $5 \% \mathrm{TCA}$ 용액을 5 배 넣은 후 원심분리 $(12,000 \mathrm{rpm}, 15$ 분)한 다음 상등액을 취하여 n-hexane 혼합하여 비극성 물질을 처리한 후 0.25 $\mu \mathrm{m}$ syringe filter에 통과시킨 후 아미노산 분석기(Hitachi L-8900, Hitachi High Technologies America, Inc., USA)로 분석하였다. 이때 column은 hitachi $4.6 \times 60 \mathrm{~mm}$ (seperation), hitachi $4.6 \times 40 \mathrm{~mm}$ (ammonia filtering)을 사용하였으며, column 온도는 $50^{\circ} \mathrm{C}$, mobile phase는 buffer set(PH-SET KANTO), flow rate $(\mathrm{mL} / \mathrm{min})$ 는 buffer 0.4 , ninhydrin 0.35 , injection volume은 $20 \mu \mathrm{L}$ 였다.

\section{추출물의 isoflavonoids 분석}

상황버섯균 배양 황기의 $80 \%$ 에탄올 및 열수 추출물 성분 함량분석은 HPLC(Waters 2695, Waters Co., Miliford, $\mathrm{MA}, \mathrm{USA})$ 를 이용하여 분석하였다. 각 추출물을 $0.45 \mu \mathrm{m}$ PVDF membrane filter 여과한 것을 시험용액으로 하였고, 분석 조건은 다음과 같다. column은 YMC-Pack Pro C18(5 $\mu \mathrm{m}, 4.6 \times 250 \mathrm{~mm}, \mathrm{YMC}$ Co.), mobile phase 조성은 solvent A water: thrifluoro-acetic $\operatorname{acid}(99.5: 0.5, \mathrm{v} / \mathrm{v})$ 와 solvent $\mathrm{B}$ Acetonitrile를 사용하였고, flow rate 및 column 온도는 각각 $0.8 \mathrm{~mL} / \mathrm{min}, 30^{\circ} \mathrm{C}$ 로 detector는 photodiode array detector (Waters 2699, Waters Co.)를 사용하여 검출하였다. 표준물 질은 calycosin-7-o- $\beta$-d-glucoside, ononin, calycosin 및 formononetin을 Sigma-Aldrich Co.로부터 구입하였고 HPLC에서 나타난 peak area의 3회 반복 평균값을 취한 후 표준물질의 양과 peak area사이의 상관관계를 도출하여 검 량선을 작성하여 계산하였다.

\section{통계처리}

본 실험의 결과는 3회 반복 실험을 실시한 뒤 평균과 표준편차로 나타내었으며, 각 실험결과에 대한 통계분석은 SPSS 22.0 program(Statistical Package for Social Sciences, SPSS Inc, Chicago IL, USA)을 이용하여 ANOVA를 실시한 후 Duncan's multiple range test 방법을 사용하여 각 처리구 간의 유의적 차이를 검증하였다 $(\mathrm{p}<0.05)$.

\section{결과 및 고찰}

배양기간 중 황기의 이화학적 특성 변화

상황버섯균을 접종하여 30 일간 배양한 황기의 수분함량, $\mathrm{pH}$, 산도 및 환원당 함량을 측정 결과는 Table 1.과 같다. 수분함량 측정 결과 대조구 즉, 상황버섯균 무 접종 황기로 0 일차는 $52.95 \%$ 의 함량을 보였고, 배양 $10,20,30$ 일차 황기 배양물은 각각 $54.73 \%, 55.77 \%, 56.63 \%$ 로 배양기간이 지남 에 따라 서서히 증가하는 경향을 보였으며 전반적으로 균사 체 배양 황기의 수분함량은 약 $50 \%$ 이상으로 대조구보다 높았으며, 배양 30 일차 가장 높은 수분함량을 나타내었다. 이는 육안을 통해서 균사체의 증식이 양호한 것을 확인한 바와 같이 배양기간이 지남에 따라 균사체의 생장으로 인해 수분함량이 꾸준히 증가한 것으로 판단된다. $\mathrm{pH}$ 는 균사체 배양기간이 지남에 따라 0 일차 $\mathrm{pH} 5.8410,20$ 일차 5.84, 30 일차 5.82로 증가하였다가 감소되는 경향을 보였으나 큰 차이는 보이지 않았다. $\mathrm{Kim}$ 등(17)은 $\mathrm{pH}$ 4 5범위의 산성에 서 담자균의 생장 및 배양이 양호하며, 구름버섯 및 말똥 진흙버섯 배양액이 발효기간이 지남에 따라 계속적으로 $\mathrm{pH}$ 가 상승하여 $\mathrm{pH} 6$ 이상까지 도달하였다는 결과와 유사 하였다. 반면 산도는 배양기간이 지남에 따라 유의적으로 감소하는 경향을 보였는데 배양 0 일차 $0.46 \%$ 로 총 산도가 가장 높았으며 이후 배양 $10,20,30$ 일차 각각 $0.32 \%, 0.35 \%$, $0.31 \%$ 로 초기 산도에 비해 감소하였다. 이러한 결과는 오미 자 열매 추출액이 젖산 발효가 진행됨에 따라 $\mathrm{pH}$ 가 증가하

Table 1. The moisture content, $\mathrm{pH}$, total acid and reducing sugar contents of Astragalus memvranaceus fermented with Phellinus linteus

\begin{tabular}{ccccc}
\hline \multirow{2}{*}{$\begin{array}{c}\text { Fermentation } \\
\text { time (day) }\end{array}$} & $\begin{array}{c}\text { Moisture } \\
\text { content }(\%)\end{array}$ & $\mathrm{pH}$ & Total acid (\%) & $\begin{array}{c}\text { Reducing sugar } \\
(\mathrm{g} / 100 \mathrm{~g}, \%)\end{array}$ \\
\hline 0 & $52.95 \pm 0.42^{1 / 22)}$ & $5.68 \pm 0.01^{\mathrm{a}}$ & $0.46 \pm 0.01^{\mathrm{c}}$ & $0.32 \pm 0.01^{\mathrm{a}}$ \\
10 & $54.73 \pm 0.49^{\mathrm{b}}$ & $5.84 \pm 0.01^{\mathrm{b}}$ & $0.32 \pm 0.01^{\mathrm{a}}$ & $0.36 \pm 0.01^{\mathrm{b}}$ \\
20 & $55.77 \pm 0.15^{\mathrm{c}}$ & $5.84 \pm 0.01^{\mathrm{b}}$ & $0.35 \pm 0.01^{\mathrm{b}}$ & $0.42 \pm 0.00^{\mathrm{c}}$ \\
30 & $56.63 \pm 0.56^{\mathrm{d}}$ & $5.82 \pm 0.02^{\mathrm{b}}$ & $0.31 \pm 0.01^{\mathrm{a}}$ & $0.61 \pm 0.01^{\mathrm{d}}$ \\
\hline
\end{tabular}

${ }^{1)}$ Values are mean \pm SD $(n=3)$.

${ }^{2}$ Means with different superscript in the same column are significantly different at $\mathrm{p}<0.05$ by Duncan's multiple range tests. 
고 적정산도는 감소한 결과와 유사하였으며, 일반적인 젖 산발효 양상과 대비 되는 것으로 발효가 진행되면서 산성을 나타내는 유기산의 일부분이 소비되며, 세포내 탈 탄산효 소에 의해 다른 물질로 전환되면서 발효물의 산도를 감소시 키거나 유지하는 경향을 나타낸다는 연구결과가 보고된바 있다(18). 환원당 함량을 측정한 결과 배양기간에 따른 함량 차이를 나타냈다. 배양 30 일차 환원당 함량은 $0.61 \mathrm{~g} / 100$ $\mathrm{g}$ 으로 가장 높은 환원당 함량을 나타냈으며 대조구 환원당 함량 $0.32 \mathrm{~g} / 100 \mathrm{~g}$ 에 비해 약 2 배 높은 환원당 함량을 나타냈 었다. 이는 담자균을 곡물에 배양하여 발효 시 배양기간이 지남에 따라 효소활성이 증가되었고, 이러한 결과는 $a$ -amylase를 생성하는 미생물들이 발효식품 제조에서 전분 질 원료를 당화시키는 것으로 알려져 있으며(19)이 더불어 fungamyl 처리한 황기의 환원당 함량이 시간이 지남에 따라 증가하였다는 보고(20)와 본 연구결과는 유사한 결과를 나 타냈다.

\section{추출용매에 따른 추출수율}

상황버섯균 접종 황기에 대한 $80 \%$ 에탄올 용매 및 열수 추출에 대한 추출수율 결과는 Table. 2에 나타내었다. 열수 추출물은 40.18 41.99\%의 비슷한 수율을 보였고, 그 중 담 자균 무접종 황기 즉, 대조구가 $41.99 \%$ 로 높은 수율을 나타 냈다. 반면 에탄올 추출물은 $28.70 ~ 33.18 \%$ 로 열수추출물 보다 낮은 수율을 보였으며, 배양 30 일차의 경우 대조구에 비해 수율이 약 1.2 배 증가하였으므로 배양기간이 지남에 따라 수율이 점진적으로 증가하는 결과를 보였다. 이러한 결과는 용매에 따른 추출수율이 상반되는 것으로 사료 되며 $\operatorname{Kim}$ 등(21)와 같이 버섯균사체를 이용한 연잎 발효의 경우 와 유사한 결과를 가지는 것을 알 수 있었다.

Table 2. Extraction yield of Astragalus memvranaceus fermented with Phellinus linteus

\begin{tabular}{ccc}
\hline \multirow{2}{*}{$\begin{array}{c}\text { Fermentation } \\
\text { time (day) }\end{array}$} & \multicolumn{2}{c}{ Yield (\%) } \\
\cline { 2 - 3 } & $80 \%$ EtOH ext. & Water ext. \\
\hline 0 & $28.70 \pm 0.89^{1)}$ & $41.99 \pm 1.02$ \\
10 & $29.72 \pm 0.16$ & $41.00 \pm 0.54$ \\
20 & $30.96 \pm 1.79$ & $40.18 \pm 1.66$ \\
30 & $33.18 \pm 1.39$ & $41.58 \pm 0.29$ \\
\hline
\end{tabular}

${ }^{1)}$ Values are mean \pm SD $(\mathrm{n}=3)$.

\section{추출물의 유리당 함량 변화}

상황버섯균 접종 황기의 추출용매별 유리당 함량을 측정 한 결과는 Table 3.과 같다. $80 \%$ 에탄올 및 열수 추출물의 유리당은 fructose, sucrose가 함유되어 있는 것으로 나타났 으며, 이는 Kim 등(22)의 연구에 따르면 황기에 함유된 유리 당은 fructose, glucose와 sucrose 3 가지이나 열수 추출물 및 $50 \%$ 에탄올 추출물에서는 glucose가 검출되지 않았고 $75 \%$
에탄올 추출물에서 미량 검출 되었다는 보고와 유리당 조성 이 유사한 경향을 나타내었다. $80 \%$ 에탄올 추출물의 대조 구 경우 fructose $0.58 \%$ 및 sucrose $11.40 \%$ 로 검출되었으며, 전반적으로 배양기간이 지남에 따라 fructose, sucrose 함량 이 미미하게 감소하는 경향을 보였다. 열수추출물 또한 대 조구의 유리당 함량은 fructose, sucrose 각각 $0.51 \%$ 및 $9.67 \%$ 로 $80 \%$ 에탄올 추출물과 유사한 결과를 나타내었다. 즉, 상황버섯균사체 발효로 인해 에탄올 및 열수 추출물의 유리당 함량은 배양기간이 지남에 따라 감소되었음을 알 수 있었다. 이상의 결과는 본 연구에서 사용된 상황버섯균 사체의 가수분해효소 활성에 의하여 단당류 등으로 분해된 후 균사체의 증식에 따른 당 소비로 인해 배양기간이 지남 에 따라 감소한 함량을 나타내었으며, 또한 추출 시 극성도 가 다른 각 추출용매에 따라 당 용출의 차이로 상이한 유리 당 함량 결과를 나타낸 것으로 사료된다.(19-24)

Table 3. The free sugar content of Astragalus memvranaceus fermented with Phellinus linteus

\begin{tabular}{ccccc}
\hline \multirow{2}{*}{$\begin{array}{c}\text { Fermentation } \\
\text { time(day) }\end{array}$} & \multicolumn{4}{c}{ Content $(\mathrm{g} / 100 \mathrm{~g}, \%)$} \\
\cline { 2 - 5 } & \multicolumn{2}{c}{$80 \%$ EtOH ext. } & \multicolumn{2}{c}{ Water ext. } \\
\cline { 2 - 5 } & Fructose & Sucrose & Fructose & Sucrose \\
\hline 0 & $0.58 \pm 0.07^{1)(2)}$ & $11.40 \pm 0.49^{\mathrm{b}}$ & $0.51 \pm 0.05^{\mathrm{b}}$ & $9.67 \pm 0.12^{\mathrm{b}}$ \\
10 & $0.53 \pm 0.03^{\mathrm{c}}$ & $9.76 \pm 0.70^{\mathrm{a}}$ & $0.41 \pm 0.03^{\mathrm{a}}$ & $8.63 \pm 0.88^{\mathrm{a}}$ \\
20 & $0.47 \pm 0.01^{\mathrm{b}}$ & $9.73 \pm 0.37^{\mathrm{a}}$ & $0.41 \pm 0.01^{\mathrm{a}}$ & $9.27 \pm 0.23^{\mathrm{ab}}$ \\
30 & $0.44 \pm 0.04^{\mathrm{a}}$ & $9.87 \pm 0.46^{\mathrm{a}}$ & $0.40 \pm 0.01^{\mathrm{a}}$ & $9.63 \pm 0.11^{\mathrm{b}}$ \\
\hline
\end{tabular}

${ }^{1)}$ Values are mean \pm SD (n=3).

${ }^{2)}$ Means with different superscript in the same column are significantly different at $\mathrm{p}<0.05$ by Duncan's multiple range tests.

\section{추출물의 유리아미노산 함량 변화}

상황버섯균 접종 황기의 $80 \%$ 에탄올 추출물의 배양기간 에 따른 아미노산의 함량변화는 Table 4 와 같다. 총 아미노 산 함량은 필수아미노산 8 종을 포함해서 총 17 종이 검출되 었다. 아미노산의 총 함량은 배양기간이 지남에 따라 20 일 까지 소폭 증가하였으나 30 일차 감소하는 결과를 보였다. 이는 균사체의 protease활성으로 황기의 단백질이 가수 분 해됨으로써 아미노산 생성 증가에 기인하여 함량이 증가하 며(25), 시간이 지남에 따라 미생물 증식이 왕성해짐으로써 아미노산의 생성보다 소비 증가로 인해 아미노산 함량이 감소한 것으로 판단된다.(26) 그 중 배양 20일차가 121.47 $\mathrm{mg} \%$ 으로 다른 배양일차 보다 다소 증가한 함량을 나타냈 고, 배양 0 일차인 $105.68 \mathrm{mg} \%$ 에 비해 약 1.2 배 높은 함량을 나타났다. 즉, 배양 20 일차의 경우 arginine이 $38.05 \mathrm{mg} \%$ 로 구성성분 중 가장 높았으며, 그다음으로 alanine이 19.91 $\mathrm{mg} \%$, aspartic acid $10.23 \mathrm{mg} \%$, valine $8.94 \mathrm{mg} \%$, leucine $6.04 \mathrm{mg} \%$, serine $5.77 \mathrm{mg} \%$, glycine $4.51 \mathrm{mg} \%$, isoleucine $4.27 \mathrm{mg} \%$ 순으로 나타났다. 그 외에도 glutamic acid, cystine, 
methionine, tyrosine, phenylalanine, lysine, histidine 등이 검 출되었다. 반면 0일차의 경우 arginine이 $35.02 \mathrm{mg} \%$, alanine 이 $18.90 \mathrm{mg} \%$, aspartic acid $9.77 \mathrm{mg} \%$, valine $7.19 \mathrm{mg} \%$, leucine $5.21 \mathrm{mg} \%$, serine $4.35 \mathrm{mg} \%$, threonine $4.05 \mathrm{mg} \%$, phenylalanine $3.36 \mathrm{mg} \%$ 순으로 나타났으며, 또한 배양 10 일차의 경우도 arginine이 $37.23 \mathrm{mg} \%$, alanine이 $19.88 \mathrm{mg} \%$, aspartic acid $9.80 \mathrm{mg} \%$, valine $8.34 \mathrm{mg} \%$, leucine $6.05 \mathrm{mg} \%$,

Table 4. Amino acid content of Astr agalus memvranaceus fermented with Phellinus linteus

(unit: $\mathrm{mg} / 100 \mathrm{~g}$ )

\begin{tabular}{ccccc}
\hline \multirow{2}{*}{ Amino acid } & \multicolumn{4}{c}{ Fermentaion time (day) } \\
\cline { 2 - 5 } & 0 & 10 & 20 & 30 \\
\hline Aspartic acid & 9.765 & 9.795 & 10.234 & 8.621 \\
Threonine & 4.051 & 5.243 & 5.958 & 5.895 \\
Serine & 4.346 & 5.414 & 5.771 & 5.160 \\
Glutamic acid & 3.053 & 3.659 & 3.792 & 3.738 \\
Glycine & 2.670 & 4.105 & 4.505 & 3.950 \\
Alanine & 18.897 & 19.883 & 19.908 & 16.283 \\
Valine & 7.188 & 8.339 & 8.935 & 8.160 \\
Cystine & 1.759 & 1.848 & 2.019 & 1.908 \\
Methionine & 0.528 & 0.521 & 0.535 & 0.538 \\
Isoleucine & 3.360 & 4.196 & 4.274 & 3.754 \\
Leucine & 5.205 & 6.050 & 6.036 & 5.631 \\
Tyrosine & 2.556 & 3.095 & 2.749 & 2.812 \\
Phenylalanine & 3.362 & 3.723 & 3.790 & 3.401 \\
Tryptophan & $\mathrm{ND}$ & $\mathrm{ND}$ & $\mathrm{ND}$ & $\mathrm{ND}$ \\
Lysine & 2.174 & 2.833 & 3.034 & 3.113 \\
Histidine & 1.756 & 1.883 & 1.874 & 1.880 \\
Arginine & 35.016 & 37.233 & 38.054 & 37.811 \\
\hline Total amino acid & 105.683 & 117.819 & 121.470 & 112.655 \\
\hline
\end{tabular}

${ }^{1)} \mathrm{ND}$, No detection.<smiles>COc1ccc(-c2coc3cc(O[C@@H]4O[C@H](CO)[C@@H](O)[C@H](O)[C@H]4O)ccc3c2=O)cc1O</smiles>

compound 1. (calycosin-7-O- $\beta$-glucoside)<smiles>COc1ccc(-c2coc3cc(O)ccc3c2=O)cc1O</smiles>

Compound 3. (Calycosin) serine $5.41 \mathrm{mg} \%$, threonine $5.24 \mathrm{mg} \%$, isoleucine $4.20 \mathrm{mg} \%$ 순으로 나타났다. 배양 30 일차에서는 arginine이 37.81 $\mathrm{mg} \%$ alanine이 $16.28 \mathrm{mg} \%$, aspartic acid $8.62 \mathrm{mg} \%$, valine $8.16 \mathrm{mg} \%$, threonine $5.90 \mathrm{mg} \%$, leucine $5.63 \mathrm{mg} \%$, serine $5.16 \mathrm{mg} \%$, glycine $3.95 \mathrm{mg} \%$ 순으로 나타났으며, 배양기간 동안 아미노산 중에서 tryptophan은 검출 되지 않았다.

이상의 결과에서 상황버섯균 접종 황기의 주요 아미노산 은 arginine, alanine, aspartic acid 및 valine 으로 arginine, valine은 약한 쓴맛을 alanine 및 aspartic acid는 감칠맛을 나타내는 것으로 알려져 있다. 이러한 본 연구 결과를 미루 어 볼 때 아미노산의 조성과 함량은 균 사용 여부 및 원료 및 발효기간 등의 조건에 기인하며(27) 미생물을 활용한 발효로 다양한 특성을 가진 아미노산의 증가 뿐만(28) 아니 라 독특한 향미를 제공할 수 있을 것으로 사료된다.

\section{추출물의 isoflavonoids 함량 변화}

상황버섯균 무접종 황기와 균 접종 배양한 황기의 추출 용매에 따른 성분 함량 측정하기 위해 황기에 존재하는 생리활성 물질로 isoflavonoids 성분인 calycosin-7-o- $3-d-$ glucoside, ononin, calycosin 및 formononetin 4종의 성분을 확인하였으며 구조는 Fig. 1와 같고, HPLC chromatogram은 Fig. 2에 분석결과는 Table 5에 나타냈다. 대조구 즉, 0 일차 의 $80 \%$ 에탄올 추출물은 calycosin-7-o- $\beta$-d-glucoside 21.58 $\mathrm{mg} / 100 \mathrm{~g}$, ononin $28.93 \mathrm{mg} / 100 \mathrm{~g}$, calycosin이 $16.98 \mathrm{mg} / 100$ $\mathrm{g}$, formononetin이 $11.54 \mathrm{mg} / 100 \mathrm{~g}$ 의 함량을 나타냈고, 열수 추출물은 calycosin-7-o- $\beta$-d-glucoside $16.60 \mathrm{mg} / 100 \mathrm{~g}$, ononin $14.47 \mathrm{mg} / 100 \mathrm{~g}$, calycosin이 $0.45 \mathrm{mg} / 100 \mathrm{~g}$, formononetin이 $0.18 \mathrm{mg} / 100 \mathrm{~g}$ 의 함량을 나타내었는데 이는 추출용매의 극성도에 따라 성분 용출에 차이가 나므로 함량이 상이한 것으로 판단된다.(29) 균 접종 황기의 $80 \%$ 에탄올 추출물을 분석한 결과 배양기간이 지남에 따라 전반적 4종의 성분 함량이 감소하거나 미미한 차이를 나타낸 반면 열수 추출물
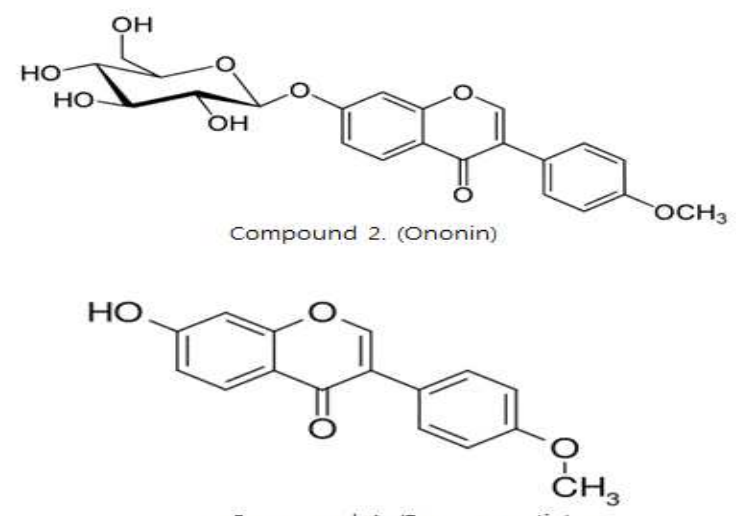

Compound 4. (Formononetin)

Fig. 1. Chemical structure of four compounds from Astragalus membranaceus fermented with Phellinus linteus. 

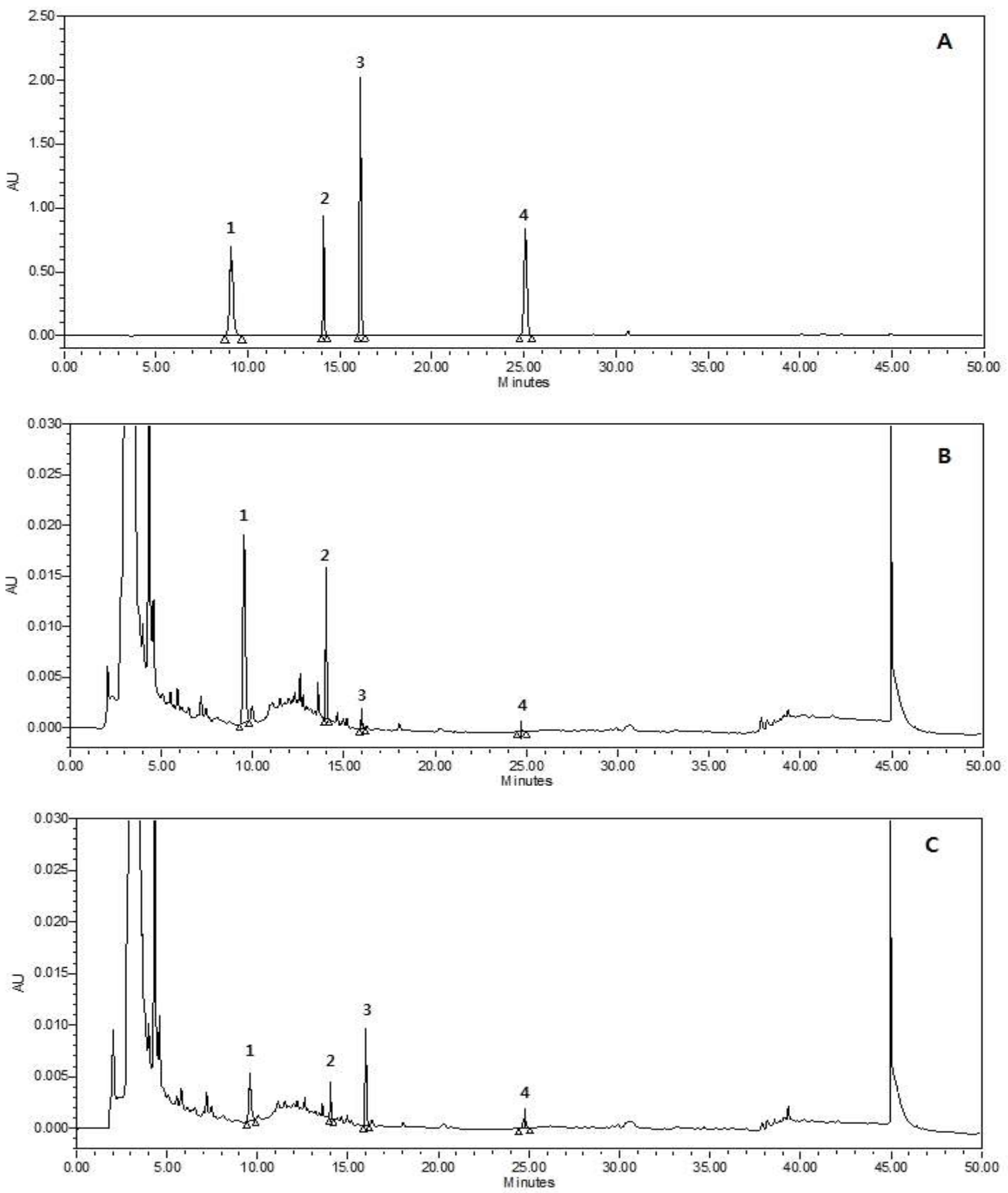

Fig. 2. HPLC chromatograms of isoflavonoid compounds.

A, standard of four isoflavonoid compounds; B, water extract of Control; $\mathrm{C}$, water extract of 30day the Astragalus membranaceus fermented with $P$. linteus, 1, calycosin-7-0- $\beta-\mathrm{d}-\mathrm{glucoside}$; 2, ononin; 3 , calycosin; 4, formononetin.

의 배양 30 일차에서 calycosin-7-o- $\beta$-d-glucoside은 3.30 $\mathrm{mg} / 100 \mathrm{~g}$, ononin은 $2.85 \mathrm{mg} / 100 \mathrm{~g}$ 으로 대조구에 비해 각각 5 배, 5.1배 감소하였으며, calycosin 및 formononetin 함량은 $3.91 \mathrm{mg} / 100 \mathrm{~g}, 1.38 \mathrm{mg} / 100 \mathrm{~g}$ 으로 대조구에 비해 각각 8.7 배
와 7.7배 증가한 함량으로 다른 배양일 보다 유의적으로 높은 함량을 나타내었다. 따라서 본 실험의 결과를 토대로 보았을 때 황기에 다량 존재하는 calycosin, formononetin 의 배당체형태인 calycosin-7-o- $\beta$-d-glucoside 및 ononin 
Table 5. The content of major isoflavonoids of Astragalus memvranaceus fermented with Phellinus linteus

\begin{tabular}{|c|c|c|c|c|c|c|c|c|}
\hline \multirow{3}{*}{$\begin{array}{l}\text { Fermentation } \\
\text { time (day) }\end{array}$} & \multicolumn{8}{|c|}{ Content (mg/100 g, dry weight) } \\
\hline & \multicolumn{4}{|c|}{$80 \% \mathrm{EtOH}$ extract } & \multicolumn{4}{|c|}{ Water extract } \\
\hline & $\begin{array}{l}\text { Calycosin-7-0- } \beta-d \\
\text {-glucoside }\end{array}$ & Ononin & Calycosin & Formononetin & $\begin{array}{l}\text { Calycosin-7-O- } \beta-d \\
\text {-glucoside }\end{array}$ & Ononin & Calycosin & Formononetin \\
\hline 0 & $21.58 \pm 1.68^{1 /(2)}$ & $28.93 \pm 2.47^{\mathrm{c}}$ & $16.98 \pm 0.76^{b}$ & $11.54 \pm 0.35^{\mathrm{b}}$ & $16.60 \pm 0.98^{d}$ & $14.47 \pm 1.73^{\mathrm{d}}$ & $0.45 \pm 0.07^{\mathrm{a}}$ & $0.18 \pm 0.03^{\mathrm{a}}$ \\
\hline 10 & $19.43 \pm 1.19^{c}$ & $26.41 \pm 0.71^{\text {bc }}$ & $15.99 \pm 0.19^{\mathrm{ab}}$ & $12.38 \pm 1.34^{b}$ & $12.70 \pm 0.33^{\mathrm{c}}$ & $10.44 \pm 0.15^{\mathrm{c}}$ & $0.88 \pm 0.22^{\mathrm{a}}$ & $0.19 \pm 0.10^{\mathrm{a}}$ \\
\hline 20 & $18.49 \pm 1.01^{\mathrm{b}}$ & $24.56 \pm 0.75^{b}$ & $15.79 \pm 0.53^{\mathrm{ab}}$ & $9.70 \pm 0.27^{\mathrm{a}}$ & $9.87 \pm 0.31^{\mathrm{b}}$ & $7.83 \pm 0.49^{b}$ & $3.58 \pm 1.70^{\mathrm{b}}$ & $1.23 \pm 0.14^{\mathrm{b}}$ \\
\hline 30 & $15.23 \pm 0.92^{\mathrm{a}}$ & $19.97 \pm 1.55^{\mathrm{a}}$ & $15.27 \pm 1.21^{\mathrm{a}}$ & $9.66 \pm 0.84^{\mathrm{a}}$ & $3.30 \pm 0.28^{\mathrm{a}}$ & $2.85 \pm 0.08^{\mathrm{a}}$ & $3.91 \pm 0.11^{\mathrm{b}}$ & $1.38 \pm 0.65^{\mathrm{b}}$ \\
\hline
\end{tabular}

${ }^{1)}$ Values are mean $\pm \mathrm{SD}(\mathrm{n}=3)$.

${ }^{2)}$ Means with different superscript in the same column are significantly different at $p<0.05$ by Duncan's multiple range tests.

(Formononetin-7-O- $\beta$-d-glucoside) 성분이 aglycon 형태로 전환이 된 것으로 이는 배양과정 중 Phellinus linteus의 효소 분해 작용으로 인해 유기물을 분해하고 전환시켜 함량이 증가한 것으로 사료된다. 이는 $\operatorname{Im}$ 등(30)이 Viscozyme 등의 당분해효소를 처리하여 배당체 형태의 성분을 비배당체 형태로 전환하고, 한약재 추출물을 lactobacillus균로 발효 하여 nodakenin을 aglycon인 nodakenitine으로 전환시킨 보 고(31)와 유사하였으며, 이러한 균 발효공정을 통한 약용소 재 활성성분의 생물전환은 약재의 효능 증가 및 새로운 효능 도출 할 수 있으며, 체내 이용 및 흡수율 증진 시켜 여러모로 식품산업에서 폭넓은 활용이 가능할 것으로 판단 된다(32).

\section{요 약}

본 연구에서는 상황버섯 균사체를 황기에 배양하여 이용 성 및 기능성을 증진시킨 식품 및 소재를 개발하기 위한 연구의 일환으로 기초연구를 실시하였다. 수분함량, $\mathrm{pH}$, 산도 및 환원당을 측정함으로서 균사체 배양 황기의 변화를 관찰한 결과 수분함량 및 $\mathrm{pH}$ 는 균사체 배양기간이 지남에 따라 유의적으로 증가하는 경향을 보인 반면 산도는 시간이 지남에 따라 오히려 대체적으로 감소하는 경향을 나타냈 다. 환원당 함량 측정결과 배양 30 일차 황기가 대조구에 비해 약 2 배 증가한 $0.61 \mathrm{~g} / 100 \mathrm{~g}$ 으로 가장 높은 함량을 나타냈고, 배양 10,20 일차는 각각 $0.36,0.42 \mathrm{~g} / 100 \mathrm{~g}$ 으로 대조구보다 다소 증가한 함량을 나타냈다. 추출용매에 따 른 균사체 배양 황기의 추출수율 결과 열수추출물이 $40.18 \sim 1.99 \%$ 범위로 $80 \%$ 에탄올 추출물의 $28.70 ~ 33.18 \%$ 보다 높게 나타났다. 유리당 함량 분석결과 $80 \%$ 에탄올 추출물 및 열수추출물의 모든 실험구에서 배양기간이 지남 에 따라 fructose 및 sucrose의 함량이 감소하는 경향을 나타 내었다. 유리아미노산은 필수아미노산 8종을 포함해서 총 17 종이 검출되었으며 상황버섯균 배양 황기의 주요 아미노 산은 arginine, alanine, aspartic acid 및 valine 으로 확인되었
다. 아미노산의 총 함량은 배양기간이 지남에 따라 20 일차 까지 소폭 증가 한 뒤 30 일차 감소하였으며, 그 중 배양 20 일차가 $121.47 \mathrm{mg} \%$ 으로 배양일 중 가장 증가한 함량을 보였다. 상황버섯균 배양 황기의 성분 함량을 분석한 결과 열수 추출물의 배양 30 일차에서 calycosin-7-o- $\beta$-d-glucoside 은 $3.30 \mathrm{mg} / 100 \mathrm{~g}$, ononin은 $2.85 \mathrm{mg} / 100 \mathrm{~g}$ 으로 대조구에 비해 각각 5 배, 5.1 배 감소하였으며, calycosin 및 formononetin 함량은 $3.91 \mathrm{mg} / 100 \mathrm{~g}, 1.38 \mathrm{mg} / 100 \mathrm{~g}$ 으로 대조 구에 비해 각각 8.7배와 7.7배 증가한 함량으로 다른 배양일 보다 유의적으로 높은 함량을 나타내었다. 이는 황기에 존 재하는 배당체인 calycosin-7-o- $\beta$-d-glucoside 및 ononin (Formononetin-7-O- $\beta$-d-glucoside) 성분이 aglycon 형태로 전환이 된 것으로 사료된다. 이러한 분석결과는 상황버섯 균사체 배양을 통한 황기의 이화학적특성 변화를 초래하여 기능성을 증대 시킬 수 있음을 확인하였고, 추후 긍정적 영향을 미칠 수 있는 천연소재로서 산업적 활용이 가능할 것이라 생각된다.

\section{감사의 글}

본 연구는 농촌진흥청 국립농업과학원 농업과학기술 연 구사업(과제번호: PJ01012202)의 지원에 의해 이루어진 것 이며 이에 감사드립니다.

\section{References}

1. Jung JH, Wee JJ, Shin JY, Cho JH, Jung HD (2005) Antioxidative effect of crude saponin fractionn prepared from culture product of basidiomycota cultured with fresh ginseng as substrate. Korean J Food Sci Technol, 37, 67-72

2. Park HS, Kim BH, Choi HS, Kim JM, Kim MK (2010) Enzyme activity of Basidiomycetes products in each 
cereals. J Mushroom, 8, 102-108

3. Baek NI, Kim YS, Kyung JS, Park KH (1996) Isolation of and hepatotoxic from the root of Astragalus membranceus. Korean J Pharmacogn, 27, 111-116

4. Jung HS, Lee EJ, Kim JS, Kang SS (2008) Phytochemical studies on Astragalus membranceus root (3): Triterpenoids and sterols. Korean J Pharmacogn, 39, 186-193

5. Ryu MS, Kim EH, Chun MS, Kang SH, Shim BS, Yu YB, Jeong GJ, Lee JS (2008) Astragali Radix elicits anti-inflammation via activation of MKP-a, concomitant with attenuation of p38 and Erk. J Ethnopharmacol, 115, 184-193

6. Inoue $\mathrm{K}$, Shirai $\mathrm{T}$, Ochiai $\mathrm{H}$, Kasao M, Hayakawa $\mathrm{K}$, Kimura M (2003) Blood-pressure-lowering effect of a novel fermented milk containing $\mathrm{\gamma}$-aminobutyric acid in mild hypertensives. Eur J Clin Nutr, 57, 490-495

7. Yin Y, Heo SI, Jung MJ, Wang MH (2009) Antiioxidant and antidiabetic effects of various sections of Astragalus membranaceus. Korean J Pharmacogn 40, 1-5

8. Bae EA, Han MJ, Kim EJ, Kim DH (2004) Transformation of gingeng saponins to ginsenoside $\mathrm{Rh} 2$ by acids and human intestinal bacteria and biological activities of their transformants. Arch Pharm Res, 27, 61-67

9. Cho SI, Kim HW, Lee GJ (2006) Biological activites of extracts of fermented Camellia japonica leaf and flower. Korean J Herbol, 21, 55-62

10. Toth JO, Luu B, Ourisson G (1983) Triterpenes cytotoxiques de Ganoderma lucidum (Polyporaceae). Tetrahedron Letters, 24, 1081-1084

11. Jung IC, Kim SH, Kwon YI, Kim SY, Lee JS, Park S, Park KS, Lee JS (1997) Cultural condition for the mycelial growth of Phellinus igniarius on chemically defined medium and grauins. Korean J Mycology, 25, 133-142

12. Han SY, Shon MY, Lee SW (2003) Physiological activities of mycelial Flammulina velutipes cultured in liquid grain media. Korean Food Ind Nutr, 8, 50-56

13. Jung IC (2006) Manufacturing and sensory characteristics of Jupjang using grains fermented by Basidiomycetes. Korean J Food Cookery Sci, 22, 337-345

14. Choi HD, Seong HM, Park YK, Kim JA (2007) Hypoglycemic effects of Basidiomycetes mycelia and cereals fermented with Basidiomycetes. J Korean Soc Food Sci Nutr, 36, 1257-1262

15. Kim DS, Roh JH, Cho CW, Ma JY (2012) Analysis of nodakenetin from Samultangs fermented by lactose bacteria strains. Korean J Herbol, 27, 35-39

16. Park CS, Lee TS (2002) Quality characteristics of Takju prepared by wheat flour Nuruks. Korean J food Sci Technol, 34, 296-302

17. Kim SH, Lee JS, Park KS, Lee JS, Lee HW, Park S (1999) Liquid culture of Basidiomycetes on natural media. Korean J Mycol, 27, 373-377

18. Lee HS, Kwon SY, Lee SO, Lee SP (2016) Production of fermented Omija (Schizandra chinensis) beverage fortified with high content of gamma-amino butyric acid using Lactobacillus plantarum. Korean J Food Preserv, 23, 326-334

19. Park HS, Kim BH, Choi HS, Kim JM, Kim MK (2010) Enzyme activity of Basidiomycetes products in each cereals. J Mushroom, 8, 102-108

20. Kwon SC, Choi GH, Hwang JH, Lee KH (2010) Physicochemical property and antioxidative activity of hot water extracts from enzyme hydrolysate of Astragalus membranaceus. J Korean Soc Food Sci Nutr, 39, 406-413

21. Kim JS, Wang SB, Kang SK, Cho YS, Park SK (2009) Quality properties of white lotus leaf fermented by mycelial Paecilomyces japonica. J Korean Soc Food Sci Nutr, 38, 594-600

22. Kim HG, Lee BY, Seok HM, Jeon MJ (1994) Astragalus membranaceus to use the development of processed foods. Korea Food Research Institute

23. Jung IC, Ha HC, Kwak HJ (2002) Comparison of free sugar content in grains fermented with mycelia of the Basidiomycetes. J Applied Tourism Food Beverage Management Research, 13, 69-80

24. Choi JH (2005) Physiological activity and isoflavone composition of soybean products prepared with some different strains. MS Thesis, Sunchon National University, Korea

25. Lew ID, Park CK, Ju HY (1988) Interaction between Lactobacillus acidophilus and Kluyveromyces fragilis on the metabolism of amino acids in soymilk. Journal of Microbiology and Biotechnology, 16, 287-292

26. Park YS, Suh CS (1995) Change in soluble protein, free amino acid and starch of Jeungpyun dough during fermentation. Korean J Food Cook Sci, 8, 282-286

27. Youn Y, Jeon SH, Yoo JH, Jeong DY, Kim YS (2016) Quality characteristics of tangerine peel Soksungjang prepared from different koji strains. Korean J Food Preserv, 23, 117-126

28. Baek SY, Kim JS, Mun JY, Lee CH (2016) Quality characteristics of detoxified Rhus verniciflua vinegar 
fermented using different acetic acid bacteria. Korean J Food Preserv, 23, 347-354

29. Kim GS, Lee DY, Lee SE, Noh HJ, Choi JH, Park CG, Choi SI, Hong SJ, Kim SY (2013) Evaluation on extraction conditions and HPLC analysis method for bioactive compounds of Astragali Radix. Korean J Medicinal Crop Sci, 21, 486-492

30. Im KR, Kim MJ, Jung TK, Yoon KS (2010) Analysis of isoflavonoid contets in Astragalus membranaceus bunge cultivated in different areas and at various ages. KSBB J, 25, 271-276

31. Lee KJ, Song NY, Roh JH, Liang C, Ma JY (2013) Analysis of bioconversed-components in fermented Jaeumganghwa-tang by Lactobacillus. J Appl Biol Chem, 56, 131-135

32. Cho SI, Kim HW, Lee GJ (2006) Biological activites of extracts of fermented Camellia japonica leaf and flower. Korean J Herbol, 21, 55-62 